\title{
Liberal Democracy: Culture Free? The Habermas-Ratzinger Debate and its I mplications for Europe
}

\author{
PABLO C JIMÉNEZ LOBEIRA \\ Australian National University \\ pablojiminez@anu.edu.au
}

\begin{abstract}
The increasing number of residents and citizens with non-Western cultural backgrounds in the European Union (EU) has prompted the question of whether EU Member States (and other Western democracies) can accommodate the newcomers and maintain their free polities ( Iiberal democracies'). The answer depends on how important - if at all - cultural groundings are to democratic polities. The analysis of a fascinating Habermas-Ratzinger debate on the pre-political moral foundations of the freestate' suggests that while legitimacy originates on the will of the citizens that conform the political community, liberal democracies might not be completely free from moral principles implicit in their political culture. This possibility has normative implications for the political future of the EU-and of the West in general-particularly regarding immigration, integration and citizenship policies.
\end{abstract}

Keywords: Europe, J udeo-Christianity, moral pre-political foundations, cultural background, political culture, Enlightenment, Western liberal democracies

\section{Introduction $^{1}$}

In J anuary 2004 two prominent European intellectuals met for a discussion on the moral foundations of the constitutional state. One of them was from Germany's west (Düsseldorf, North-Rhine-Westphalia), the other from the south (Marktl am Inn, Bavaria). Both were born in the 1920s and received their doctoral degrees in the 1960s. Each of them became a leading thinker in his respective fields of study. One represented the values of the Enlightenment. The other advocated those of J udeo-Christianity. The

\footnotetext{
${ }^{1}$ I would like to sincerely thank Professor Simon Bronitt, Dr Matthew Zagor, Dr J ohn Besemeres, Dr Ben Wellings, Dr Vito Breda, Christian Wicke, the editors of this journal, two anonymous reviewers, and participants at the Round Table on Constitutional Patriotism held at the ANU Centre for European Studies in Canberra, 27 August 2010, for invaluable comments and suggestions regarding both style and contents, to earlier versions of this paper.
} 
encounter has not been the only one either of them has had with thinkers of backgrounds sharply contrasting with his own. Habermas was to hold discussions with members of the J esuit School of Philosophy in Munich. Ratzinger had had similar encounters with Italian atheists Paolo Flores and Marcello Pera. Books would follow from each event. 2 As one might expect, strong dissimilarities appeared between Habermas's and Ratzinger's views. But interestingly, there were also parallels.

For Habermas, the democratic constitutional state is self-sufficient in terms of the normative justification for its existence. Its democratic constitution intrinsically engenders legitimacy, and its foundations are post-metaphysical. What the state cannot generate is the solidarity essential for the participation of citizens in lawmaking and the discussion of the common good. The millenary religious traditions can be very useful to attend this shortfall. In the post-secular age, state neutrality is an essential precondition for the democratic participation of citizens. Religious worldviews cannot to be discarded a priori as irrational: secularists must acknowledge that secularism can become a worldview.

For Ratzinger, history provides examples of laws that can be unjust, even when approved by overwhelming majorities. This raises the question of whether legality is a synonym of legitimacy, and whether laws - even democratically approved ones constitute the standard of justice. If they do not, the question is where that standard can be found, and who can prescribe it. Ratzinger seems to suggest that such standard - the moral foundations of Western political culture - is to be found in the Enlightenment and J udeo-Christianity. He acknowledges that religion has in the past given occasion to wars and divisions, and that in its fundamentalist forms it can be a pretext for terrorism today. He also points out that enlightened reason has shown a capacity not only for good, but also for new forms of destruction and manipulation of human beings. In Europe, religion and secularism - which to a certain extent share a common rationalitycan serve to balance and 'purify' each other from their excesses. ${ }^{3}$

\section{The problem of the normative foundations}

The debate touched on the political culture within which the democratic constitutional state has flourished. Has it arisen from a specific (though only implicit) moral background, or has its development been independent from pre-political cultural elements? To put this in perspective, let me quote Professor J oseph HH Weiler:

One possible explanation for the success of...'Western Liberal Democracy" is...the J udeo-Christian tradition, which persists in three ways...: one...,

\footnotetext{
${ }^{2}$ Habermas et al., An Awareness of What is Missing - Faith and Reason in a Post-Secular Age, Cambridge, Polity Press, 2010. Ratzinger, J \& Flores d'Arcais, P, Dios, ¿existe? ('Does God exist?'), (trans. Carmen Bas Álvarez \& Alejandro Pradera Sánchez), México, Espasa-Calpe, 2009. Ratzinger, J \& Pera, M, Without Roots - The West, Relativism, Christianity, Islam (trans. Micahel F Moore) New York, Basic Books, 2006.

${ }^{3} \mathrm{~J}$. Habermas and J . Ratzinger, Dialectics of Secularization: On Reason and Religion (trans. Brian McNeil) San Francisco, Ignatius, 2006, p. 77-79.
} 
restraint in the relationship between Church and State...second,...selfrestraint...in the exercise of power... Thirdly, the idea of the rule of law. 4

For him, J udeo-Christianity forms part of the moral foundations from which the political culture of achieving liberal democracies derive. ${ }^{5}$

So when Habermas claims that no pre-political foundations are required for a free constitutional state, does he mean that citizens make politics abstracted from their culture (is politics culture-free)? Alternatively, when Ratzinger stresses the importance of J udeo-Christianity and the Enlightenment to understand Western democracies, does he mean that immigrants must become J ewish or Christian (or convinced Kantians for that matter)?

These questions need to be addressed in part through historical and empirical studies. ${ }^{6}$ But they also call for a theoretical, normative investigation. These are the parameters within which the Habermas-Ratzinger debate was held. In my view, one of the most important normative implications of the discussion was this: if certain moral foundations are essential to a successful constitutional democracy, then those foundations ought to be kept and cherished not only on account of their circumstantial value (some citizens happen to hold them dear), but also due to their intrinsic value as a source of cohesion and normative grounding for free political communities.

\section{A procedural foundation or sola ratio}

For Habermas the very doubt about constitutional democracy being able to renew the normative presuppositions of its existence from its own sources would be indeed 'an

\footnotetext{
${ }^{4}$ J .H.H Weiler, Europe's Struggle with Itself - Perspectives from a WanderingJ ew' Letter for Europe 9 (J uly) 2006, <http:// www.europe4christ.net/index.php?id=54\&no_cache=1>, accessed 21 November 2009.

5 Throughout this paper the adjective liberal' denotes to a form of government that citizens choose freely. Unless specified (for instance when Habermas defines his own position), liberalism' here does not mean a specific stand within this broad theoretical conception ( 'belonging to the free-state'), as when liberalism is opposed to communitarianism, republicanism or social democracy. Only reluctantly do I use the terms 'West' and 'Western,' utilised by many but defined by very few. 'West' as geographical position makes little sense: New Zealand is to the east of the UK, United States is east to Australia. Other definitions, for instance 'non-Communist' are outdated: imagine suggesting to Central Europeans (Hungarians, Poles, Czechs) that they are not part of 'the West.' Here I will only postulate that 'West' denotes countries such as, but not limited to, Canada, United States, United Kingdom, Sweden, Finland, Denmark, Netherlands, Luxembourg, Germany, New Zealand, Australia, Norway, Austria, or Iceland, considered 'full democracies' (see next note) and sharing a broadly similar political culture. ${ }^{6}$ For an interesting study in comparative religions dealing with these problems, see: Ratzinger, J , Truth and Tolerance - Christian Belief and World Religions (trans. Henry Taylor), Ignatius, San Francisco, 2004. On the empirical side, the 'Democracy Index' 2008' classified as 'full democracies' thirty countries (The Economist Intelligence Unity, Democracy Index', 2008, <http:// a330.g.akamai.net/ 7/330/25828/20081021195552/ graphics.eiu.com/ PDF/ Democracy\%20Index \%202008.pdf>, accessed 19 J une 2010. One might point out that, with the exception of J apan, and partially of Mauritius and South Korea (both around 30\% Christian), the other 27 countries have a Christian background. Clearly, many countries with Christian background were not in that list. If we believe this study it would appear that Christianity is, therefore, neither a necessary nor a sufficient condition, though still a contributing factor in the construction of full democracies.
} 
embarrassment to a state that was committed to neutrality in terms of its world view,' following 'what Rawls has called "the fact of pluralism."'7

Acknowledging that this is not per se an argument against the existence of moral prepolitical foundations, he goes on to analyse the question from his Kantian republican perspective. ${ }^{8}$ He considers that Europe, up to very recently considered to be 'secular,' is entering a 'post-secular' age - one of revival (or survival) of religion. ${ }^{9}$ In Habermas's own words,

...it is in the interest of the constitutional state to deal carefully with...the cultural sources that nourish its citizens' consciousness of norms and their solidarity. (...) religion is holding its own in an increasingly secular environment and...will continue to exist... [T] he "modernization of the public consciousness" involve[s] the assimilation and.. reflexive transformation of. . religious and secular mentalities. ${ }^{10}$

The state should acknowledge this fact for two reasons. Firstly, so that the process of deliberation that brings about laws and debate in the public sphere will be legitimate and accepted by all. Secondly, because 'philosophy has good reasons to be willing to learn from religious traditions.'11 In other words:

(...) the...compenetration of Christianity and Greek metaphysics ...promoted the assimilation by philosophy of genuinely Christian ideas...in normative conceptual clusters with a heavy weight of meaning, such as responsibility, autonomy, and justification; or history and remembering, new beginning, innovation, and return; or emancipation and fulfilment; or expropriation, internalization, and embodiment, individuality and fellowship. ${ }^{12}$

An outstanding example is the concept, so rooted in Western mentality, of human dignity and equality:

Philosophy...transformed the original religious meaning of ...the concept of "man in the image of God" into that of the identical dignity of all men that deserves unconditional respect.. [going] beyond the borders of one particular religious fellowship and...[making] the substance of biblical concepts accessible to...those who have other faiths or who have none. ${ }^{13}$

Habermas has no problem acknowledging an important role for religion in the democratic constitutional state. He is aware of the existence of two kinds of secularism

\footnotetext{
${ }^{7}$ Habermas \& Ratzinger, op. cit., p. 21.

${ }^{8}$ He explains this in more detail in: Habermas, J ürgen, La inclusión del otro ('the inclusion of the other', trans. J uan Carlos Velasco Arroyo), Barcelona, Paidós Básica 2004, pp. 229-258.

${ }^{9}$ Casanova, J osé ‘Public Religions Revisited' in: Hent de Vries (ed.) Religion: Beyond the Concept, Fordham University Press, 2008, pp. 101-119.

${ }^{10}$ Habermas \& Ratzinger, op. cit., pp. 46-47.

11 Ibid., p. 42

12 Ibid., p. 44

13 Ibid., pp. 44-45.
} 
that Casanova has distinguished neatly: 'secularism as statecraft principle' - a tool for the working of the polity (for instance implementing the separation between church and state), and 'secularism as ideology' - a particular worldview not unlike other cultural positions. ${ }^{14}$ Accordingly, for Habermas

The neutrality of the state authority.. is incompatible with the political universalization of a secularist worldview...[S]ecularized citizens...must not deny in principle that religious images of the world have the potential to express truth... [and that] believing fellow citizens [possess] the right to [contribute] in a religious language to public debates. ${ }^{15}$

But that does not mean that for Habermas a pre-political moral foundation, a cultural sediment in other words, is required for the constitutional state to emerge. In his exposition he dedicates the first part to explain why such a moral foundation is not necessary, and the rest (four sections) to speak about the relation between secularism and religion in the state, assuming it already exists and enjoys legitimacy and consistency of its own, without need of pre-political conditions. ${ }^{16}$ In other words,

the constitution of the liberal state can satisfy its own need for legitimacy in a self-sufficient manner, that is, on the basis of the cognitive elements of a stock of arguments that are independent of religions and metaphysical traditions.' 17

However, the constitutional state cannot command citizens to be solidary to one another, or to exercise political virtues such as active participation in the public sphere or voting. ${ }^{18}$ Habermas understands the foundations of the liberal state in a 'proceduralist' manner. He places his own position - 'deliberative democracy' - between liberalism and republicanism. ${ }^{19}$ According to his understanding, derived from the Kantian (as opposed to the Hegelian) view of law, 'the basic principles of the constitution have an autonomous justification,' rationally acceptable to all citizens. ${ }^{20}$

If the democratic process is inclusive of all citizens who - through discourse - express their opinions and engage in dialogue to reach agreements, the results of that process will be rationally acceptable to all. In order to be valid, the process must include the granting of basic liberal and political rights to all the members of the political community. The citizens, gathered in deliberation, give themselves a constitution, from

\footnotetext{
${ }^{14}$ J . Casanova. 'The Secular and Secularisms,' Social Research. Vol. 76, No. 4, 2009, pp. 1049-1066.

15 Ibid., pp. 51-52.

16 In his view '(...) "weak" suppositions about the normative contents of the communicative constitution of socio-cultural forms of life suffice to defend a non-decisionist concept of the validity of law both against the contextualism of a non-defeatist concept of reason and against legal positivism.' Ibid., p. 25.

${ }^{17}$ Ibid., p. 29.

${ }^{18} \mathrm{He}$ assumes that voting is not compulsory, as is the case in most countries, Germany included. In a few countries, however (Australia for instance) voting is compulsory.

${ }^{19}$ Habermas, J , 'Political Communication in Media Society: Does Democracy Still Enjoy an Epistemic Dimension? The Impact of Normative Theory on Empirical Research' Communication Theory, Vol. 16, No. 4, 2002, p. 411-426.

${ }^{20}$ Habermas \& Ratzinger, op. cit., p. 28.
} 
which state authority emanates and which is subjected to the rule of law as its most inner core. Political power is totally permeated by the law. In the constitutional state 'there is no ruling authority derived from something antecedent to the law' such as religion or some other basis of its validity. ${ }^{21}$ Systems of law

...can be legitimated only in a self-referential manner, that is, on the basis of legal procedures born of democratic procedures... If one sees them as a method whereby legitimacy is generated by legality, there is no "deficit of validity" that would need to be filled by the ethical dimension. ${ }^{22}$

Thus the democratic constitutional state is self-sufficient or autonomous in terms of its justification. ${ }^{23}$ If a tradition had to be invoked as the basis for its understanding that would be mainly the Enlightenment (and only remotely Christianity). But that is only a question of sources, not of intrinsic requirements for a democratic constitutional state to exist and be legitimate.

What then becomes of Weiler's assertion that the success of 'Western liberal democracies' is due in part to their J udeo-Christian underpinnings? Habermas seems to imply that no such tradition is necessary. Arguably, a political community with members of any cultural background could build a successful constitutional democracy, as long as they follow the procedures of discourse and deliberation.

This opens the possibility of creating cosmopolitan, post-metaphysical, even 'postnational' states (a possible reading of the European Union) which transcend differences in worldviews and where the political culture relies only on clear legal and discursive procedures.

\section{A moral foundation, or fides et ratio}

Ratzinger is not completely convinced that good procedures will themselves suffice to ground constitutional states. For him, politics must apply the criterion of law to power, so that it is not the law of the stronger, but the strength of the law which will hold sway. Yet, applying the criterion of the law to power leads to a further question:

How does law come into being, and what must be the characteristics of law if it is to be the vehicle of justice rather than the privilege of those who have the power to make this law? It is...the question of the genesis of the law... [and] of its own inherent criteria. ${ }^{24}$

\footnotetext{
${ }^{21}$ Ibid., pp. 26-27.

22 Ibid., pp. 27-28.

${ }^{23}$ Even though 'Christian theology' of 'the Middle Ages' and 'especially' the late Spanish Scholasticism' are present in the genealogy of human rights '(...) ultimately, however, the bases of legitimation of a state authority with a neutral worldview are derived from the profane sources of the philosophy of the seventeenth and eighteenth centuries (...) if I have understood it correctly, the Catholic tradition.. has no problem...vith an autonomous justification of morality and law (...independent of the truths of revelation).' Ibid., pp. 24-25.

24 Ibid., pp. 58-59.
} 
The law must express the common interest of society, and this seems to have been resolved through democracy, since everybody participates in creating that law and keeping power limited by standards of justice foreseen in the legal system itself. Because of this, democracy appears as the most appropriate form of political order. ${ }^{25}$ So far Ratzinger has essentially agreed with Habermas. But he is still not satisfied:

(...) the process of forming a democratic will relies necessarily either on an act of delegation or else on a majority decision... But majorities, too, can be blind or unjust, as history teaches very plainly. When a majority oppresses a religious or a racial minority by means of unjust laws, can we still speak in this instance of justice or, indeed, of law? ${ }^{26}$

There are in fact numerous examples in recent European history of laws and delegations that were approved democratically and yet held dubious ethical standards. ${ }^{27}$ Because of this, the law is not the ultimate foundation of justice:

(...) the majority principle always leaves open the question of the ethical foundations of the law [,] ... of whether there is something that can never become law but always remains injustice; or.. something... [which is] of its very nature inalienably law... antecedent to every majority decision... [and that] must be respected by all such decisions. ${ }^{28}$

With the Enlightenment a number of such normative elements came to be included in the various declarations of human rights, which to a certain extent have been withdrawn from subjection to the changing verdicts of majority voting. ${ }^{29}$ However these values are not obvious outside the Western world. China's government regards them with suspicion as a possible invention belonging to the culture of the West, and Islam has defined its own catalogue of human rights. ${ }^{30}$ Ratzinger therefore points to a moral foundation that precedes the law and that provides criteria by which the justice of actual laws can be assessed:

\footnotetext{
25 Ibid.

${ }^{26}$ Ibid., pp. 59-60.

${ }^{27}$ For instance, on 7 April 1933 the German government passed The Law for the Restoration of the Professional Civil Service (Gesetz zur Wiederherstellung des Berufsbeamtentums), which banned from civil service people of non-Aryan descent and targeted especially J ews. Hitler had been legally appointed German Chancellor on 30 J anuary 1933, after his party became the largest in the Reichstag in 1932. The Civil Service Law was clearly unjust. J ustice and (p0sitive) law seem not to be the same, therefore. The former provides a standard to measure the latter. Another, more recent case could be the polemic laws banning the wearing of face veils in France, which came into effect in April 2011. Even though the majority of French citizens approve of the law, it is still being contested by many as unjust. Both examples are mine, and by no means do I intend to suggest they are equivalent-the legitimacy of the government in each case, the reach of the discriminatory measure, and the historical context are very different.

28 Habermas \& Ratzinger, op. cit., pp. 60-61.

29 The Universal Declaration of Human Rights was approved in 1948 by a majority of the then United Nations Organisation member countries (48 out of 56, with 8 abstentions). These "universal" human rights have become principles of international law in many cases. But, were they to be voted again, it is not sure they will be approved unopposed. The Cairo Declaration of Human Rights in Islam, adopted by the 45 member countries of the Organisation of the Islamic Conference in 1990, presents an alternative view of human rights, for example.

30 Habermas \& Ratzinger, op. cit., pp. 60-61.
} 
There are then, let us say, self-subsistent values that flow from the essence of what it is to be a man, and are therefore inviolable: (...) human rights. . are incomprehensible without the presupposition that man..., thanks simply to his membership in the species "man", is the subject of rights and that his being bears within itself values and norms that must be discovered - but not invented. 31

For him the doctrine of human rights should also include obligations and human limitations, and renewed consideration of the possible existence of a rationality of nature and consequently a rational law for man and for his existence in the world. ${ }^{32}$ This dialogue should be intercultural and not only Enlightened and J udeo-Christian, because while it is true that these two traditions claim to be de jure universal, de facto they are not. 33 Western concepts of human rights, rule of law, separation of church and state, and so on, have been born in specific cultural contexts that must be acknowledged and cannot be automatically reproduced in the whole of mankind. ${ }^{34}$

To be sure, Ratzinger finds himself 'in broad agreement' with Habermas 'about the postsecular society, about the willingness to learn from each other, and about the selflimitation on both sides' - secular and religious rationalities. He speaks of 'pathologies in religion' which are extremely dangerous (for example the justification of terrorism) and that make it necessary to see 'the divine light of reason as a "controlling organ." Religion 'must continually allow itself to be purified and structured by reason.' 35

At the same time, there are also 'pathologies of reason' with a hubris that is no less dangerous. Atomic bombs and eugenics are also products of reason. Therefore 'reason, too, must be warned to keep within its proper limits, and it must learn a willingness to listen to the great religious traditions in mankind.'36 Reason and faith, secularism and religion need one another to keep each other in balance. And even though in a global context the two main partners in this mutual relatedness are biblical faith and enlightened rationality, this process should be encouraged also in other cultural traditions receptive to the essential complementarity of reason and faith. ${ }^{37}$

Ratzinger therefore is aware of the cultural diversity that is an evident fact in today's Europe. At the same time he maintains that, at their cultural core, the West is grounded on the J udeo-Christian faith and the rationality of the Enlightenment. This must be the starting point for an understanding between different cultures.

31 Ibid., pp. 71-72.

32 Ibid.

33 Ibid., p. 75.

34 Ibid., p. 76.

35 Ibid., p. 77.

36 Ibid., p. 78.

37 '.. so that 'a universal' (i.e., trans-cultural) 'process of purifications can proceed.' Ibid., p. 79. 


\section{The normative foundations of the European polity}

The two visions are by no means equivalent, but they are in many ways compatible. Departing from different perspectives they share common ground in their conception of the relation between secularism and religion. They differ, however, in their understanding of the normative foundations of liberal democracies.

It becomes apparent how secular rationality and religious faith can 'purify,' enrich and balance each other within constituted states. Religion accepts a secular political order, in which it can aspire to be heard in the public sphere, for example by promoting a specific vision of the common good. To do this it must translate its discourse into a language that everybody can understand. Secularism accepts that neutrality means an agnostic state, committed to no worldview - even a secularist one. The state should not be 'anti-religious.' Secularism as an ideology has no right to place itself above alternative (including religious) worldviews.

In their debate, both Habermas and Ratzinger attempt a theoretical analysis that challenges contextual limitations. It is undeniable, however, that at the same time they develop their ideas against a certain implicit (and sometimes explicit) contextual background when they discuss the relations between secularism and religion. To begin with, both have as a point of reference their common Vaterland, in whose recent history examples of the 'pathologies' either of religion or reason are patent.

A second contextual circle beyond Germany is the European Union and wider Europe. Europe has been the main arena of 'secularisation', and now of a 'post-secular' age; of Christianity and post-Christianity; of Enlightenment (modernity) and post-modernity. Europe is today, as well, a place of cultural encounters brought about by the advent of massive immigration and the resurgence of its fastest growing religion: Islam. This encounter has created new questions and challenges to Europe's former selfunderstanding as either J udeo-Christian or Enlightened - or both.

The experiment is being watched by other Western democracies outside Europe. This is the third contextual circle. The fourth is the international community, which is increasingly interconnected thanks to the development of globalisation. Both the Enlightenment and J udeo-Christianity have, to different extents, reached all four circles.

Let us now consider the problem of the normative foundations of the democratic constitutional state in the context of the European project. The European Union is today a 'polity of sorts,' analogical to constituted democracies. ${ }^{38}$ It is a project that, according to federalists, has not gone long enough towards a federal state (the usual point of comparison is the United States). For intergovernmentalists, it has already advanced

\footnotetext{
${ }^{38}$ For an excellent study on the nature of the EU see: D. Chryssochoou, Theorizing European Integration,
} (Second Edition), Routledge, Oxford, 2009. 
dangerously far in that direction. Finally for advocators of a mixed regime, the EU needs to be perfected from its present form, but not substantially changed. 39

The idea of elaborating a 'Constitution for Europe' was in part aimed at 'solving the impasse' in which the federation idea found itself, tackling a growing perception that the project lacked legitimacy, and finding or creating a feeling of belonging for the citizens of the Union. That attempt however opened the Pandora box of 'European identity,' with a sharp debate about whether God and Christianity should be mentioned in the Preamble to the European Constitution, as the preambles to constitutions of at least half of the EU Member States do. ${ }^{40}$ What was the source of commonality for Europeans? Christianity and the Enlightenment? a deliberative public sphere? their 'social model'? their international image as a 'normative power'? or cosmopolitanism? ${ }^{41}$

The question was not resolved (and the Constitution rejected after referenda in France and the Netherlands). But it became clear that the EU was trying to find or create a political identity. For some, this problem of identity is being exacerbated thanks to the growing presence of Islam. This is, for instance, Caldwell's thesis. ${ }^{42}$ If the cultural crisis of Europe has indeed been catalysed by problems like immigration and refugee policy (e.g. in Italy and Spain), criteria for EU expansion (especially to Turkey), integration of 'culturally diverse' citizens and residents (like in France), and the resurgence of far-right parties in countries which up to recently were famous for their openness and tolerance (The Netherlands, Denmark, Sweden, Finland,...) Caldwell may have a point. In today's Europe the Habermas- Ratzinger debate acquires the utmost relevance, a relevance that matters for other parts of the West too. It is against this background that I would like to present some conclusions.

\section{Keeping liberal democracies liberal- and democratic}

A first conclusion is that Habermas and Ratzinger seem to have fairly compatible views regarding the relationship between secularism and religion in the public sphere. Though the model itself is under discussion, both thinkers seem to regard its principles as sound. 'Secularism' as an agnostic statecraft principle promises the best known arrangement for democracy. 'Secularism' as an ideology deserves the same place as other worldviews (whether religious or not), but does not have the right to claim the 'monopoly of culture' in the public sphere.

\footnotetext{
39 I have considered both the "analogical" character of the EU and the three positions regarding the "political form" of the EU in: Pablo CJ iménez Lobeira, "Exploring an Analogical Citizenship for Europe," Open Citizenship - The J ournal Vol. 1, Autumn 2010.

40 J.H.H Weiler, Un' Europa cristiana - Un saggio esplorativo ('A Christian Europe - an Exploratory Essay') Milan, BUR, 2003, pp. 53-84.

${ }^{41}$ For an analysis of positions on and conceptions of European identity see: Pablo CJ iménez Lobeira, "Normative Conceptions of European Identity - a Synthetic Approach," Australian J ournal of Professional and Applied Ethics 12, no. $1 \& 2$ (2010). — _ "EU Analogical Identity - or the Ties That Link (without Binding)," Australia National University Centre for European Studies Briefing Paper Series 1, No. 2 (2010).

42 See Caldwell, Christopher, Reflections on the Revolution in Europe. Can Europe Be the Same with Different People in It?, London, Penguin, 2009.
} 
Ratzinger expands on the usefulness of mutual 'purification' and balance between the core cultural traditions of Europe (and the West), namely the Enlightenment and J udeoChristianity. There are examples on how religions can and indeed have participated in the public sphere as part of the civil society. The tradition within Christianity to which Ratzinger belongs is one. The Catholic Church has attempted to contribute to the public discussion in the last 120 years through papal and other official Vatican documents 43 According to George Weigel the Catholic 'social doctrine' can be summarised in four principles: personalism or the human rights principle, which places the inalienable dignity and value of the human person' as foundation of its understanding of politics and society; the principle of common good (or communitarian principle); the principle of subsidiarity or of civil society; and the principle of solidarity or of civic friendship. ${ }^{44}$

Eloquent examples can be found on members of other denominations and religions too: Evangelicals and J ews in United States, Anglicans in the United Kingdom, Orthodox in Greece, just to mention a few. Cultural and religious traditions, through participation in the public sphere, can be sources of wisdom and solidarity among citizens. Awareness of this opportunity could help Europe to deal with its immigration, especially when the newcomers possess a strong religious (e.g. Muslim) identity.

A second conclusion, following Habermas, is that the free-state derives its legitimacy from its citizens. Ratzinger accepts that at least today democracy has proven to be the best option of government. Habermas cherishes the autonomy of the polity from any sources of legitimacy (including religious revelation claims) foreign to the community of free and equal citizens. This is secularism as statecraft - agnostic secularism. This form of secularism - with roots both in J udeo-Christianity and in the Enlightenment-an essential feature in the political culture of Western democracies, ought to be learned and accepted by new immigrants and citizens.

The third conclusion, in agreement with Ratzinger, is that the political culture of democratic polities has moral foundations that serve, for example, as standard of justice for law-making. This does not mean that the community of free and equal citizens derives its legitimacy from revelations that only a few of them believe. It only means that the political culture has a pre-political source. Religion can be an important part of culture in different ways, also in the realm of private and public morality. The origins of morality in the West, even in the enlightened West, refer - not only, but still eminently - back to the biblical tradition.

\footnotetext{
43 Often addressed not only to adherents, but also 'to all man of goodwill,' starting from Leo XIII's (1893) Rerum novarum (on 'the condition of labour') until Benedict XVI's (2009) Charitas in veritate (on 'integral development'), including the 2004 Compendium of the Social Doctrine of the Church. These documents can be found at $<\underline{\mathrm{http}}$ :// catholicsocialteaching.yolasite.com/ $>$ and and http:// www.osjspm.org/social teaching_documents.aspx $>$, accessed 15 August 2010. For an interesting study on 'the Idea of Europe' in post-World War II pontifical thought, see: A. Mahony, The Vatican and Europe: Political Theology and Ecclesiology in Papal Statements from Pius XII to Benedict XVI', International J ournal for the Study of the Christian Church, Vol. 9, No. 3, pp. 177-194.

${ }^{44}$ G. Weigel, The Church's Social Doctrine in the Twenty-First Century', Logos 6 (2) Spring, 2003, $<$ http:// muse.jhu.edu/journals/logos/toc/ log6.2.html >accessed 16 J uly, 2010, pp. 17-18.
} 
Caldwell affirms that 'European secularism is set up with Christians in mind. The concepts that arise out of Muslim communities are not identical.' 45

Huntington considers (Protestant) Christianity an essential foundation of United States as a nation. ${ }^{46}$ Molony mentions Christianity - both in its Anglican and its Catholic branches - as part of the cultural and moral foundations of Australia. ${ }^{47}$ Bothwell illustrates that this is also the case in Canada. ${ }^{48}$ The 27 EU Member States today have Judeo-Christianity as a strong component of their political culture (regardless of the number of other active adherents from a religious point of view). 49

Habermas himself cannot avoid speaking about the 'springs that well forth spontaneously - springs that one may term "pre-political,"' found in civil society in which citizens are embedded. Those pre-political energies motivate citizens to care not only about their own individual interests, but also about the common good, and to practice the political virtues that are 'essential if a democracy is to exist.'50 Even Habermas's very conception of constitutional patriotism is not completely free from cultural backgrounds. It relies on the historical context of each nation and on the the principles of justice' that have penetrated.. the complex of ethical orientations in a given culture. 51

\section{Some normative implications for the EU}

It follows from the preceding analysis that Western polities ought to open discussion about the moral grounds of their political culture. This might imply the acknowledgement of a place for biblical values in their history and culture. ${ }^{2}$ Less contested is, at least for the moment, the cultural place of the Enlightenment's values in the political culture of Europe. 53

The integration of citizens, whose cultural background rests on Islam and other religions, depends on their finding an explicit definition of the political cultural values that have made the EU what it is today, and choosing to abide by these values. ${ }^{54}$ At the

${ }^{45}$ C. Caldwell, op. cit., p. 159.

46 S. Huntington, Who are We?, New York, Simon \& Schuster, 2004, pp. 81-106.

${ }^{47} \mathrm{~J}$. Molony, Australia, Our Heritage. A History of a Nation, Canberra, Australian Scholarly Publishing, 2005.

48 R Bothwell, The Penguin History of Canada, Toronto, Penguin, 2006.

${ }^{49}$ Caldwell, op. cit.

50 Habermas \& Ratzinger, op. cit., pp. 30-31.

51 Ibid., pp. 33-34.

52 Something tremendously difficult to accept for the contemporary political class in Europe, if judged by the debate on the mention of 'God' and 'Christianity' in the preamble of the constitutional treaty mentioned above.

53 There is of course a clear push towards 'post-modernity' and 'post-secularity' but that has not undermined yet a general consensus about 'modern values' in liberal democracy. For interesting comments on this subject see Habermas \& Mendieta (2010).

${ }^{54}$ Acknowledgement of a J udeo-Christian moral substrate in Europe's political culture does not mean, of course, demanding of new EU citizens that they convert to J udaism or Christianity. This demand is not met by the large number of Europeans who subscribe to neither of these religions or even to any religion at all. Rather, it would only mean awareness about the roots of morality as manifested in, for example, 
same time, their increased democratic weight as they come to represent a greater proportion of Europe's population) will allow them the possibility of calling for a reshaping of the polity.

EU Muslim citizens might have different ideas about democracy, if the views of influential spiritual leaders such as Yusuf Al-Qaradawi are representative:

(...) a Christian could accept secularism without any qualms of conscience (...) For Muslim societies,... as Islam is a comprehensive system of worship ( $i b a d a h)$ and legislation (Shari ah), the acceptance of secularism means abandonment of Shari 'ah, a denial of the divine guidance and a rejection of Allah's injunctions...55

Alternatively, they might agree with Benazir Bhutto, who saw Islam as committed 'not only to tolerance and equality but [also] to the principles of democracy.'56

Today's Europeans (and citizens of Western democracies in general) ${ }^{57}$ can and should be open to immigration from culturally different people. At the same time they ought to be aware of their own culture, and the elements within it that are essential in order to

Western law. See: D. Goldman, Globalisation and the Western Legal Tradition. Recurring Patterns of Law and Authority. Law in Context. Cambridge University Press, 2007, pp. 52-76).

55 Al-Qaradawi, Yusuf, 'Secularism v Islam' In: How the Imported Solutions Disastrously Affected Our Ummah, 2010, pp. 113-4, <http://islamicweb.com/ beliefs/cults/ Secularism.htm>, accessed J une 2010. According to Der Spiegel, Al-Qaradawi is 'one of the most influential contemporary Muslim scholars.' Through his Al-J azeera talk show, 'Sharia and Life' along with his website Islam Online Al-Qaradawi reaches millions of people across the Muslim world. He is also a leading figure for millions of Muslims in Europe (Spiegel Online, 'God Has Disappeared,' Interview with Al-J azeera Host, Yusuf Al-Qaradawi ,by Volkhard Windfuhr and Bernhard Zand, 9 of September, 2005. at: http://www.spiegel.de/international/0,1518,376954,00.html $>$,accessed $10 \mathrm{~J}$ une 2010.)

56 Bhutto Benazir, Reconciliation - Islam, Democracy and the West, Harper Collins, New York, 2008, pp. 17-80. For all her efforts to promote mutual knowledge and understanding between Islam and the West, she was aware of a battle for 'the heart and soul of Islam. . between moderates and fanatics, between democrats and dictators, between those who live in the past and those who adapt to the present and plan for a better future' (ibid., pp. 19-20). For her 'in the resolution of this conflict may in fact lie the direction of international peace in the twenty-first century' (Ibid., p. 20). Unfortunately she did not live to see these developments. Extremists attempted (unsuccessfully) to assassinate her in October 2007 - 179 people died - and successfully in December 2007 - together with at least another 23 persons.

${ }^{57}$ Australia has a Muslim population of around $2 \%$ according to figures of the Australian Government (Department of Foreign Affairs and Trade, 'Muslims in Australia', <http:// www.dfat.gov.au/facts/muslims in australia.html> accessed J uly 2010. Sally Neighbour reported this year an interview with Uthman Badar, spokesman of the Islamic organisation Hizb utTahrir. According to Badar, Western democracy - now in fight with Islam - will collapse, as happened with the communist world. ('Extremists with caliphate on their minds, not bombs in their belts' The Australian, 3 July 2010, 12 am, <http:// www.theaustralian.com.au/news/ world/ extremists-withcaliphate-on-their-minds-not-bombs-in-their-belts/ story-e6frg6ux-1225887074605 >, accessed J uly 2010. Neighbour reported further that during a Hizb ut-Tahrir conference on the 4th of J uly held in Sydney, British Islamist leader Burhan Hanif recommended that Australian Muslims shun secular democracy ('Muslims told to shun democracy', The Australian, 5J uly 2010, 12 am, http:// www.theaustralian.com.au/ news/ nation/islamic-hardliners-return-for-sydney-convention-afterpush-for-ban-fails/story-e6frg6nf-1225887315042>, accessed J uly 2010. 
maintain successful democratic polities. 58 Even if the democratic state derives its legitimacy from procedures and deliberation only, the rules of the game (law) and the participants (citizens) are not free from cultural contexts. The link between the 'Western' cultural background (J udeo-Christianity and the Enlightenment) ${ }^{59}$ and successful liberal democracies (e.g. those in North America, Europe, Oceania) cannot be discarded as irrelevant. Western liberal democracies, I would like to submit, are not culture-free. They possess distinctive cultural elements manifested as well in their political life. Those elements ought to be carefully investigated, specified, and acknowledged, if liberal democracies are to continue existing as such.

This exercise in "self-awareness" could prompt the beginning of dialogue between immigrants and hosts, for the construction of renewed, intercultural societies. After all, were secular elites in Western liberal democracies, to recognise that their political systems possess cultural (even partly religious) roots they would only be joining immigrants with different cultural backgrounds in the realisation of what for the latter is all too evident.

\footnotetext{
58 The Australian citizenship test (Australian Citizenship- Our Common Bond, National Communications Branch, Department of Immigration and Citizenship, Belconnen, ACT , Australian Government, 2009) for instance, is 'designed to assess whether' applicants 'have an adequate knowledge of Australia', of 'the responsibilities and privileges of citizenship' and of English, the 'national language' (Ibid., p. 4). It teaches newcomers that Australia has a secular government, 'a J udeo-Christian heritage,' and that 'people in Australia are free to follow any religion they choose' or none (Ibid., p. 18).

59 Arguably J udeo-Christianity and the Enlightenment traditions in their present form, each in a different way, have assumed other important components of 'Western culture' such as the classical traditions of Greece and Rome.
} 